\title{
Effectiveness of Mycorrhizal Association in Revegetation
}

\author{
Hiroaki Okabe, Takuya Marumoto*, Tsugio Ezaki* and Kazuo Yamamoto*** \\ ( Forestry \& Forest Products Research Institute, Tsukuba, Ibaraki 305, Japan) \\ ( ${ }^{*}$ Faculty of Agriculture, Yamaguchi University, Yamaguchi 753, Japan) \\ (**Faculty of Agriculture, Ehime University, Matsuyama, Ehime, 790, Japan) \\ $\left({ }^{* * *}\right.$ Central Service Co., Ltd, Ube, Yamaguchi, 755-02, Japan)
}

\begin{abstract}
Selection of effective ECM (ectomycorrhizal) fungi are very important for inoculation and infection to pioneer trees. The candidates of effective ECM fungi for revegetation collected at volcanic and at poor granite sites in Japan were as follows; Pisolithus tinctorius f. tinctorius, $P$. tinctorius f. turgidus, $P$. tinctorius f. pisocarpius, Astraeus hygrometrics, Laccaria amethystea. Particularly, the elementary species $P$. tinctorius showed the widest host range and was the most common candidate of all. This fungus was associated with Pinus densiflora, Pinus Thunbergii, Betula Ermani, Betula Maximowiczii, Alnus firma, Larix leptolepis and probably Quercus serrata. Above all the association with Larix and Betula trees appeared to be efficient for the revegetation in a cool temperate zone.

Basidiospore and vegetative inocula of Pisolithus were effective for young seedlings and especially 1-year-old seedlings in volcano and granite stands. Introduction of ECM fungi to each site brought about good results for enhanced survival rate and increased growth of seedlings, especially just after sprouting, which were further promoted by using a mulching sheet made of non-woven polyester fiber.
\end{abstract}

Key words: ectomycorrhiza, Pisolithus, revegetation, mulching sheet

\section{Introduction}

Population of indigenous ECM fungi in degraded and eroded lands is generally low. Application of ECM fungi to these soils may often be effective for the prevention (Abbott,1994). Of course, beyond this it is also important to have symbionts between plants and fungi,; Rhizobium associated with legumes and Frankia associated with actinorhizal plants (nonlegumes), nodule plants or what are called soil-improving plants, and arbuscular mycorrhizal fungi associated with ca. $80 \%$ seed plants.

Plants used for revegetation are divided into two types. One is for fast revegetation which is grass, legumes, and actinorhizal plants, and the other is for slow revegetation which consists of ECM and arbuscular mycorrhizal trees. Although introduction of ECM trees, which is essential to the formation of a mature forest, is still an uncertain step, the management of forests cannot do without ECM trees. This paper examines the potential for management of ECM symbiosis.

2. Materials and methods

Candidates of ECM fungi for revegetation were surveyed and collected in eroded soils after the 
eruption of Mt. Bandai in Fukushima Prefecture in the Tohoku district, in volcanic ash soils of Mt.Sakurajima in Kagoshima Prefecture in the Kyushu district, and in poor granite soils of Mt. Tanakami in Shiga Prefecture in the Kinki district.

Distribution of ECM fungi and host-fungus specificity was investigated in every species at each site. ECM fungi were collected, isolated, cultured using MP medium (malt extract and glucose 1\%, pepton $0.5 \%$, agar $1.5 \%(\mathrm{w} / \mathrm{v}))$ at $25^{\circ} \mathrm{C}$ for a month, and examined for life form in vitro. Differences of growth was observed by putting each on substrates with agar in a petri dish. The kinds of substrate were humus, mineral soil, dung of wood lice containing humus, brown and white rot woods, and dung of silkworm containing green leaves. The preference of substrates were represented with the covering percentage of vegetative hyphae developed on substrates.

Development of ectomycorrhizas was observed on agar in petri plates and in $100 \mathrm{cc}$ plastic film tube containing sterile volcanic soil (volcanic soil : fired diatomite $=3: 2(\mathrm{v} / \mathrm{v})$ ) without fertilizer and with keeping dry condition at $20-25^{\circ} \mathrm{C}$ for a month.

Inoculation and infection by spore and vegetative hyphae of Pisolithus was done by mixing spore/water and by mixing spore/mineral soil, and by homogenized mycelium/water (Okabe,1994). To make symbionts immediately establish to each sites, after transplanting, a mulching sheet was applied with Pinus Thunbergii seedlings infected with $P$. tinctorius to active volcano in Kagoshima and well weathered granite sites in Shiga, and granite soil in a deep valley in Ehime Prefecture in the Shikoku district.

3. Results and discussion

Screening and selection of ECM fungi

Screening and selection of effective ECM fungi are very important for inoculation and infection to pioneer plants(Abbott,1994). Three forms and two species from each site were selected (Table 1);

Table 1 Trees and predominant ECM fungi occurring in natural waste lands

\begin{tabular}{clcc} 
ECM fungi & Mt. Bandai & Mt. Tanakami & Mt. Sakurajima \\
\hline 1 & -- & PD,PT & -- \\
2 & PD,PT,BE,BM & PD & -- \\
3 & PD,PT,BE,BM,LK,AF & -- & PT \\
4 & BE & PD,PT,QS & PT \\
5 & PD,PT & PD,PT,QS & PT \\
\hline
\end{tabular}

ECM fungus : 1 (Pisolithus tinctorius f. tinctorius), 2 ( $P$. tinctorius $\mathrm{f}$. pisocarpius), 3 ( $P$. tinctorius f. turgidus), 4 (Astraeus hygrometrics), 5 (Laccaria amethystea)

Tree : PD (Pinus densiflora), PT (Pinus Thunbergii), BE (Betula Ermani), BM (B. Maximowiczil), LK (Larix Kaempferi), AF (Alnus firma), QS (Quercus serrata)

Site : Mt. Bandai (dormant volcano), Mt. Tanakami (eroded granite site), Mt. Sakurajima (active volcano)

Pisolithus tinctorius f. tinctorius, P. tinctorius f. turgidus, P. tinctorius f. pisocarpius, Astraeus hygrometrics, Laccaria amethystea. Marx(1980) reported the elementary species $P$. tinctorius was one of the widest host range in ECM fungi. This fungus was associated with Pinus densiflora, Pinus Thunbergii, Betula Ermani, Betula Maximowiczii, Alnus firma, Larix leptolepis and 
probably Quercus serrata in Japan. Above all, $P$. tinctorius which was associated with Larix and Betula trees distributed in subalpine and high latitudes appeared to be efficient for revegetation in a cool temperate zone.

\section{Preferred media of ECM fungi}

Pisolithus tinctorius and Laccaria amethystea which occurred in waste lands, and Amanita rubescens and Lactarius quietus which occurred in deciduous broad-leaved forests were examined. ECM fungi occurring in waste lands preferred inorganic or poor organic media, and ECM fungi of forest types preferred organic media (Table 2). But these ECM fungi refused green leaves, probably because of the high nitrogen content. These results indicate the influence to the establishment of inoculant and mycorrhiza.

Table 2 Growth of ECM fungi in different media

Kind of medium

\begin{tabular}{ccccccccc} 
ECM fungi & 1 & 2 & 3 & 4 & 5 & 6 & 7 & 8 \\
\hline 1 & C & A & A & C & D & D & A & A \\
2 & C & B & B & C & D & D & A & A \\
3 & D & B & B & D & B & B & B & A \\
4 & D & C & C & D & B & B & B & A \\
\hline
\end{tabular}

ECM fungi: From waste lands :1 (P. tinctorius f. tinctorius), 2 (Laccaria amethystea)

From mature forests : 3 (Amanita rubescens), 4 (Lactarius quietus)

Medium: 1 (humus in deciduous broad-leaved forest), 2 (brown-rot woods of deciduous broadleaved tree), 3 (white-rot woods of deciduous broad-leaved tree), 4 (dung of wood lice, biting humus), 5 (soft zeolite), 6 (hard zeolite), 7 (fired diatomite), 8 (dung of silkworm, biting green leaves)

Growth of hyphae: (A)not grown on media, (B)less than $10 \%$ cover, (C)10-50\%, (D)more than $50 \%$

\section{Mode of life}

The life-mode of Pisolithus groups was observed under the mycorrhizal association with Pinus densiflora in plastic film tubes. Pisolithus formed sclerotia, and thick and long rhizomorphs to be able to overcome a severe condition. In fact, the infected seedling endured hard dry conditions (Okabe,1994).

Dynamics of mycorrhiza after infection

Basidiospore and vegetative inocula of Pisolithus were effective for survival and growth of young seedlings, and especially 1-year-old seedlings in granite and volcanic soils where such indigenous ECM fungi are rare. In dry sites such as eroded granite soils on Mt. Tanakami, Pisolithus mycorrhiza secured the highest rate of infection in the second year (Fig.1, Type 1). But in much more humid air such as in a deep valley in Ehime Prefecture, the mycorrhiza of Pisolithus markedly decreased and changed to indigenous groups, though the growth of the host was sharply increased (Type 2,3). On the other hand, even if seedlings without Pisolithus mycorrhiza could form indigenous mycorrhizas for the next year, the growth of the host showed a slight rise (slightly (Type 3), gradually (Type 4)). Although Type 5 resembled the pattern of Type 1, its root systems appeared to be small and poor. Probably, Type 5 may 
lands. Introduction of ECM fungi to each site brought about good results for enhanced survival rate and increased seedling growth, especially just after sprouting, compared with each control. Initial high infection rate contributed to the plant growth subsequently.

Fig. 1 Dynamics of Pinus densiflora mycorrhiza after inoculation of $P$. tinctorius f. turgidus (Ptur)

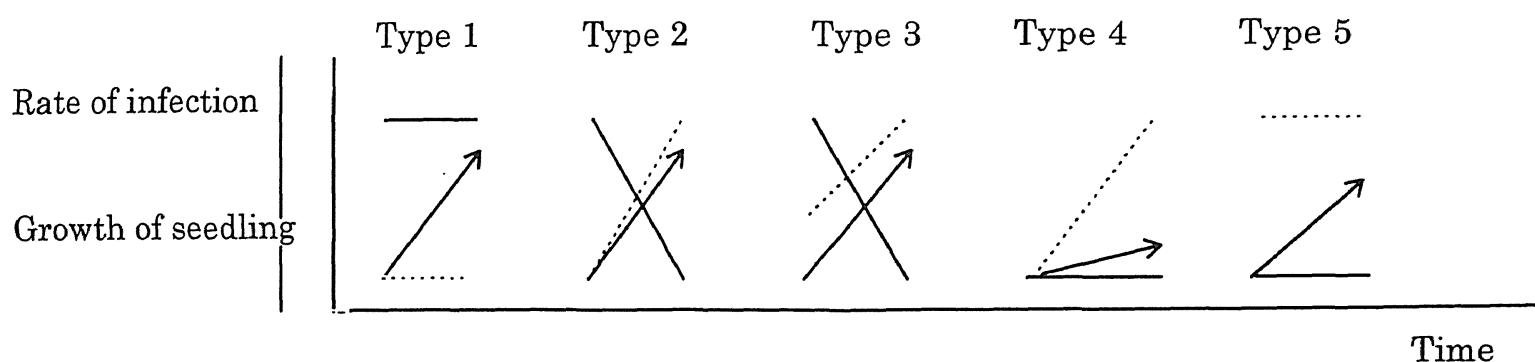

Solid : Ptur mycorrhiza. Dotted : indigenous mycorrhizas. Arrow:growth of seedling

Establishment of inoculant

Marumoto, et al.(1993) showed that a mulching sheet was effective for prevention of soil erosion and revegetation using grass. Growth of pine seedlings associated with Pisolithus was also promoted by a mulching sheet made of non-woven polyester fiber (Table 3) in Shiga . A mulching sheet had the role of accelerator for introducing and activating the feeder roots. The combination of mulching sheet and mycorrhizas was effective for revegetation.

Table 3 Influence of ECM fungi and mulching sheet on the growth of $P$. Thunbergii seedling Treatment Annual diameter increment (mm)

\begin{tabular}{ll} 
Mulching sheet & $1.63 \pm 0.42$ \\
Mulching sheet + Pisolithus tinctorius & $1.89 \pm 0.37$ \\
Pisolithus tinctorius & $1.37 \pm 0.62$ \\
Control & $0.79 \pm 0.39$ \\
\hline
\end{tabular}

\section{References}

Abbott,L.K. and Malajczuk,N.,1994: Management of mycorrhizas in agriculture, horticulture and forestry. Kluwer Academic Pub.,Dordrecht, 238p

Marumoto,T.,Hayakawa, S.,Ezaki,T.,Yamamoto,K. and Okabe,H., 1993:Effect of cover sheet on soil erosion and following planting and its application examples. In Applications of mulching materials for soil and water and conservation(ed. by Hsu, S and Wu,C.).National Pingtung Polytechnic Inst., Pingtung,49-62

Marx,D.H.,1980:Tree host range and world distribution of the ectomycorrhizal fungi Pisolithus tinctorius. Can. J. Microbiol., 23,217-223

Okabe, H.,Ezaki,T.,Marumoto,T., Hayakawa,S. and Akama,K.,1994:Application of symbiotic microorganisms to revegetation (I) Management of ectomycorrhizal fungi. Jpn. Soc. For. Env.,36,55-63 